\title{
【短 報】
}

\section{企図・動作性ミオクローヌスの病態と 反復訓練効果の検討*}

$\begin{array}{lllllll}\text { 染 } & \text { 富土子** } & \text { 尾 屟 恵子立 野 勝 彦*** } \\ \text { 洲 崎 俊男 濱 出 茂 治 } & & & \end{array}$

著者 染矢富士子 尾尻恵子 立野勝彦 洲崎俊男 濱出茂治

題名 企図・動作性ミオクローヌスの病態と反復訓 練効果の検討

要旨 臭化メチル中毒により企図・動作性ミオク口 ーヌスをきたした症例に対し単純な反復運動訓練を施 行した。 その結果, 訓練効果が一時的にみられ, 所要 時間の短縮, 動作パターンの改善傾向がみられること がわかった。しかし，その効果は持続せず，短時間の 休息で元の状態に戻り, 精神的緊張が加わるとかえっ てミオクローヌスが増悪することが観察された。この ため運動機能, ADL の改善を図ることは困難であっ たが，反復訓練によるリラクセーションがリハビリテ ーションアプローチの糸ロとなることが思惟された。

キイ・ワード：臭化メチル，企図・動作性ミオク口 ーヌス

リハ医学 $24: 117-119,1987$

企図・動作性ミオクローヌス (intention or action myoclonus 以下 IAM) は非律動的で随意運動時に出現 するミオクローススで, 本邦では1979年に神経内科領 域で初めて報告され ${ }^{1)}$, 薬物治療の面からのアプローチ がなされてきた。一般に IAM は動作企図, 外的刺激に より誘発され, 安静時には出現しないといら特徴があ り, 低酸素脳症, 薬物の急性大量中毒に続発して発症す ることが知られている。

最近筆者らは，このIAM を呈した臭化メチル中毒の 症例を経験し，興味ある病態を検討したので，ここに報 告する。

1986年 8 月 8 日受理

* Pathology of intention or action myoclonus and effect of repeating exercise.

** 金沢大学理学療法部 Fujiko SomeyA, MD, Keiko OJIRI, OTR : Division of Rehab. Medicine, Kanazawa University.

***金沢大学医療技術短期大学部 Katsuhiko Tachino, MD, Toshio Susakr, RPT, Shigeharu Hamade, RPT : School of Allied Medical Professions, Kanazawa University.

\section{I. 対 象}

対象は 61 歳の女性で，臭化メチル中毒のため IAM を呈していた。罹患後 3 カ月半経過して和り, 既にク口 ナゼパム（リボトリール®）を維持量として $3.0 \mathrm{mg} /$ 日 投与されていた。坐位, 卧位での安静時には不随意運動 はないが，四肢の随意運動開始と同時にミオクローヌス が出現し協調運動が拙劣であり，立位保持によっても常 に下肢にミオクローススが垫められた。ミオクロースス は上下肢とも近位部より遠位部の方が著明で，各々の運 動開始時と終了時で大きさは一定であり，一上肢の運動 中に対側上肢にも同時に出現することがあった．筋力， 知覚は正常で, 深部腱反射は四肢で元進していたが病的 反射はみられなかった。独歩は短距離であれば可能であ ったが，IAM のために 1 歩 1 歩踏みしめるよらな歩き 方をし、トイレに行くには手すりを要した。食事は右手 で箸，スプーンを使用して時間をかけて可能，更衣も時 間がかかるが自立していた。運動年䠲は 27.5 カ月であ った。

体性感覚誘発電位を測定すると特有な高振幅体性感覚 誘発電位 ${ }^{2)}$ が出現し，表面筋電図にて皮質反射性のC反 射増強を伴った（図１）.

\section{II. 方 法}

単純な動作を反復して行わせると不随意運動が減少 し，動きが円滑になることが観察されたので，PT では $10 \mathrm{~m}$ 歩行, 背臥位からの立ち上がりを中心に, OT で は手指の協調運動, 巧緻運動を繰り返し試行させ所要時 間を測定した。また歩行中の下肢の表面筋電図を記録 し，筋放電のパターンを調べた。

\section{III. 結 果}

$10 \mathrm{~m}$ 歩行では初回 37 歩 31.6 秒と遅く, 連続歩行に よりステップ数, 所要時間とも改善した（表1).しか し，休息により再び歩行は拙劣となった，背臥位からの 

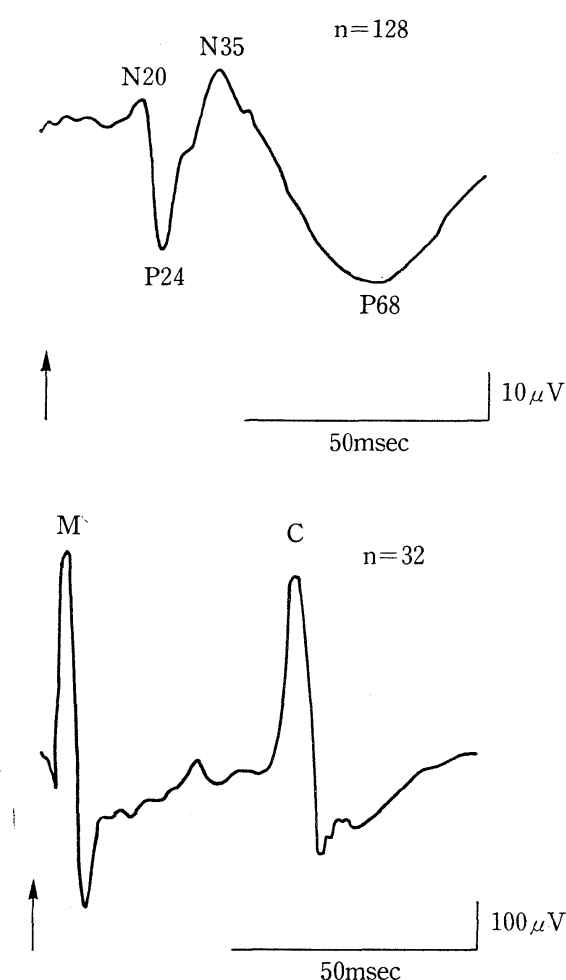

図 1 体性感覚誘発電位（上）と表面筋電図 (下). 右正中神経手根部を電気刺激すると, 高振幅体性感 覚誘発電位がみられ，右拇指球筋に潜時 $48 \mathrm{msec}$ の C反射が認められる。

立ち上がりは，初めは一度腹臥位になり四つ這い肢位よ り手をついて起き上がる方法をとったが， 3 度目の試行 より，横坐りから片滕立ちで可能となり， $4 ， 5$ 度目も 同じ方法で行った。

上肢についても，初回より 2 回目の試行で所要時間が 短くなったが（図 2)，それ以後はあまり変化せず，10 回試行後 10 分休息させるとまた所要時間が延長し 2 回 目には再び短くなった。総じて評価をしようとしたり何 か新しい動作をさせようとすると，精神的緊張が加わ り, IAM が一時的に強くなり, 試行により急速に IAM が軽減した。

下肢の表面筋電図では立位保持，歩行時にそれぞれ IAM に伴う非律動性の周波数が 17 20 サイクル程度の 筋放電が少られた（図 3)。この筋放電は歩行開始時に は共同筋，拮抗筋のすべての筋肉に同時にびまん性にみ られたが，歩行を続けていくに従い，歩行の筋収縮パタ ーンに合わせて筋放電が限局してくるよう飞なり歩行所 要時間も短くなった。 しかし， $50 \mathrm{~m}$ も歩行させるとパ ターンはそれ以上に改善せず，400 m をすぎると疲労に
表 $110 \mathrm{~m}$ 歩行化要するステップ数及び時間. 1 回目から 5 回目までは連続して歩行させ，休息の後 再試行している。

\begin{tabular}{lcrrrrr}
\hline 試行回数 & 1 & 2 & 3 & 4 & 5 & 再 1 \\
\hline $\begin{array}{c}\text { ステップ数 } \\
\begin{array}{c}\text { (歩) } \\
\text { 所 }\end{array}\end{array}$ & 37 & 26 & 23 & 24 & 22 & 36 \\
$\begin{array}{c}\text { 要 時 間 } \\
\text { (秒) }\end{array}$ & 31.6 & 16.2 & 13.3 & 14.2 & 12.5 & 28.6 \\
\hline
\end{tabular}

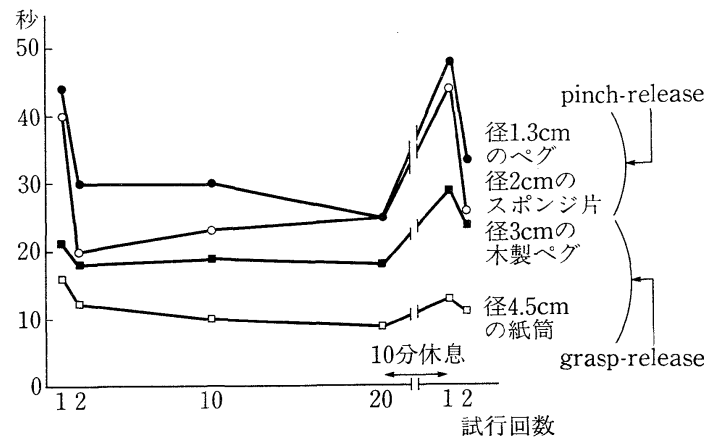

図 2 上肢基本動作試行回数に伴う所要時間の推 移。1 試行につき各々 10 個の物体を pinch なたは grasp 乙 release させている。材質，大きさを問わ ず 2 試行目で所要時間が短縮した。

より所要時間がかえって延長するようになった。IAM は疲労のために増強することはなかった。

\section{IV. 考 察}

IAM は神経内科領域で数例報告されて和り, クロナ ゼパムの投与が有効であることが知られている゙ 発症後 2 年経過しても IAM が強く残っている症例も報 告されている4)。これに対して，リハビリテーション面 からの記載はみられず，その適切なアプローチの方法を 模索した. 試みに協調運動訓練として単純な繰り返し練 習を 3 力月間連続して行った。試行中，一時的に動作は スムーズになることが観察された。しかし，最終的な練 習効果をこの期間淂ることはできず，運動年齢も変化 なかった。

臭化メチル中毒に続発するIAM の責任病巣は解剖学 的渚説あり，昏睡時の無酸素症による影響もとりあげ られている ${ }^{1,4)}$. 柴崎2)，渡辺ら ${ }^{5)}$ の脳電位を用いた分 類では，IAM は皮質反射性に発生すると述べられてい る. IAM の好発部位は四肢遠位筋，顔面の一側なたは 両側であり，本症例は四肢の両側にみられた。

共同筋，拮抗筋の同時収縮を呈する IAM は広い意味 で協調運動障害といえるが，運動失調とは異質のもので 大脳皮質の異常興奮性が原因であり深部知覚は正常であ 


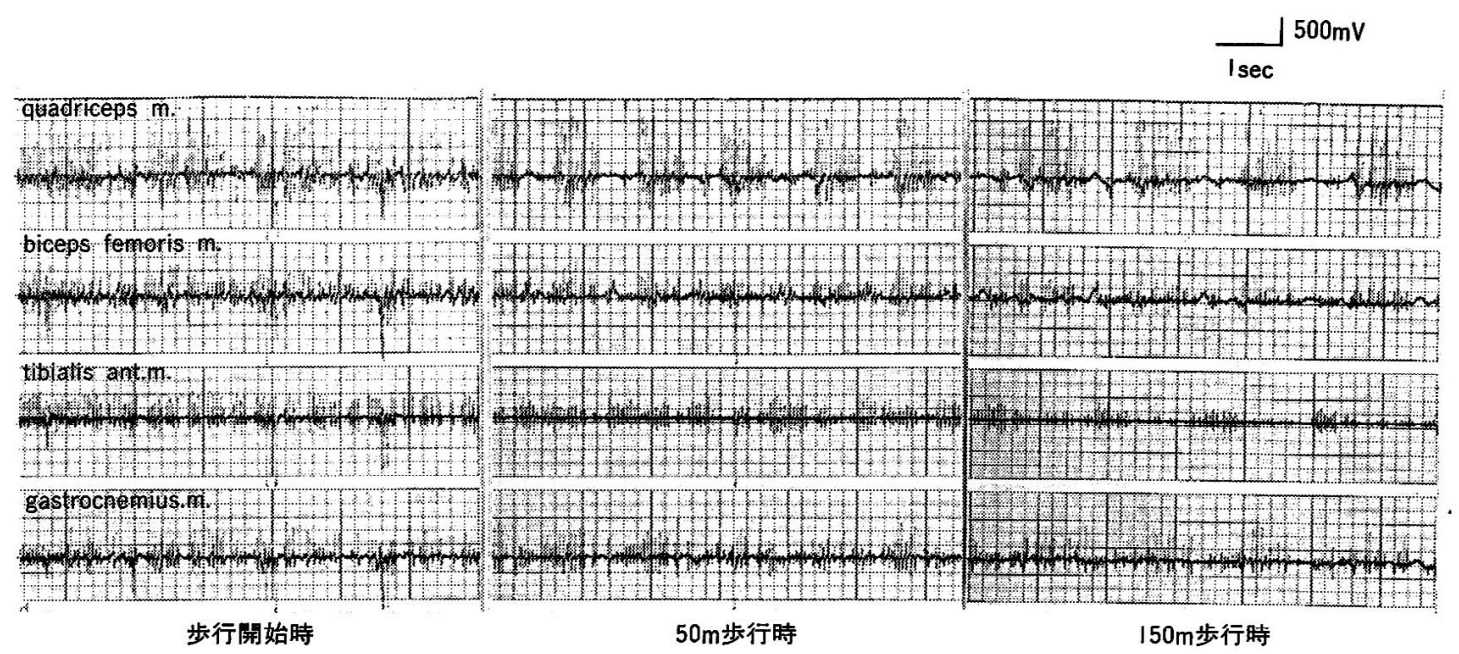

図 3 歩行時の下肢表面筋電図. 歩行開始時に比べ $50 \mathrm{~m}$ 歩行時には笳放電が限局してきているが，そ れ以上歩行させてもパターンの変化はあまりみられない.

る.また訓練効果が持続せず実生活上反映しにくいとい う問題点もあり, 今後 IAM K対寸るリハビリテーショ ンの分野からのアプローチの方法に対し更に倹討を加え ていく必要があると思われる。

\section{文 献}

1）大澤美贵雄, 成瀨清子, 井上幸子, 岡山健次 他：企図・動作性ミオクローヌスを呈した臭 化メチル中毒の 1 例。神経内科 $10: 30-37$, 1979.
2）柴崎 浩：ミオクローヌスに伴5脳電位. 神経 進歩 $28: 802-813,1984$.

3) 若山曜子, 島袋博美, 武上俊彦, 岡本 進 : 急 性ブロムワレリル尿素中畵に続発した企図・動 作性ミオクローヌスの 1 例. 最新医学 37 : 2022-2026, 1982.

4）古川哲雄：中毒性疾患とミオクロヌース，神経 進歩 $28: 767-773,1984$.

5) 渡辺 憲, 島田康夫, 豊倉康夫：ミオクローヌ スの病態生理と長経路反射 (Long-loop Reflex). 神経進歩 $28: 814-823,1984$.

お知らせ

\section{第 12 回運動療法研究会}

会 長：国立大阪南病院・理学診療科医長 博田節夫

日 時：昭和 62 年 7 月 11 日（土）午前 $10: 00$ (予定)

場 所 : 大阪行岡保健衛生学園本庄校舎 6 階講堂

大阪市北区浮田 2-2-11 06-372-2835

シンポジゥム：運動療法一基礎とその応用

1.「関節運動学の応用」/博田節夫, 宇都宮初夫先生

2. 筋生物学 (musclebiology) の応用 $\mathrm{J} /$ 米本港三 先生・他

3. 「神経生物学 (neurobiology) の応用 $J /$ 千野直一先生・他

特別講演 :「中枢神経性麻㾇患者の運動療法」/遠賀浅木内科医院院長 三好正堂 先生

演題申し込み方法 : 演題名, 所属, 発表者氏名, 住所を記入の上, 400 字以内の抄録を添え

て下記までお送りください。

演題締切：昭和 62 年 4 月 30 日

演題送付先：严586 大阪府河内長野市木戸町 677-2 国立大阪南病院

0721-53-5761 博田 節夫 